\title{
Member Bank Income and
}

\section{Expenses--1967}

$\mathbf{N}$ District continued to increase in 1967, although less rapidly than in 1966. Net income after taxes rose 8 per cent for the year compared with a 14 per cent increase a year earlier and an average annual rate of gain of 7 per cent during the 1957-67 period.

Total operating revenue rose 13 per cent in 1967 , reflecting both a larger volume of earning assets and a somewhat higher average rate of return on these assets. Expenses were up 16 per cent, with the greatest increase being interest payments on time and savings deposits. Net current earnings (operating revenue less operating expenses) rose only 4 per cent. However, the net effect of security transactions was more favorable than a year earlier, resulting in net income being up more than net current earnings.

Net income after taxes at all member banks in the nation rose 18 per cent, a much greater increase than at district banks. Gains in net current earnings at banks in the district were not greatly different from member banks in the nation, rising 4 per cent and 5 per cent respectively. A major factor in the more rapid gains in after-tax income at banks in the nation was the handling of valuation reserves and gains or losses on security transactions. While recoveries, transfers from valuation reserves, and profits on security sales rose 24 per cent from the previous year at banks in the nation, such adjustments fell 21 per cent at district member banks. Losses, charge-offs, and transfers to valuation reserves declined about one-ffth from the previous year in both the district and the nation.

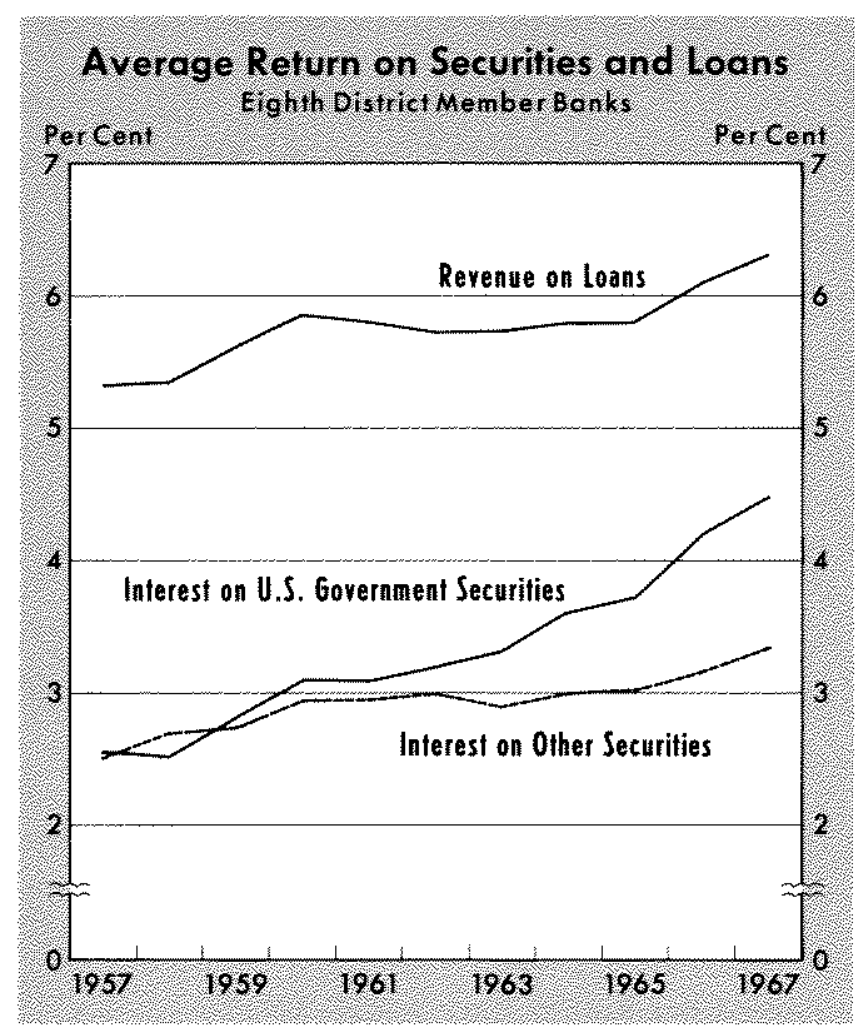




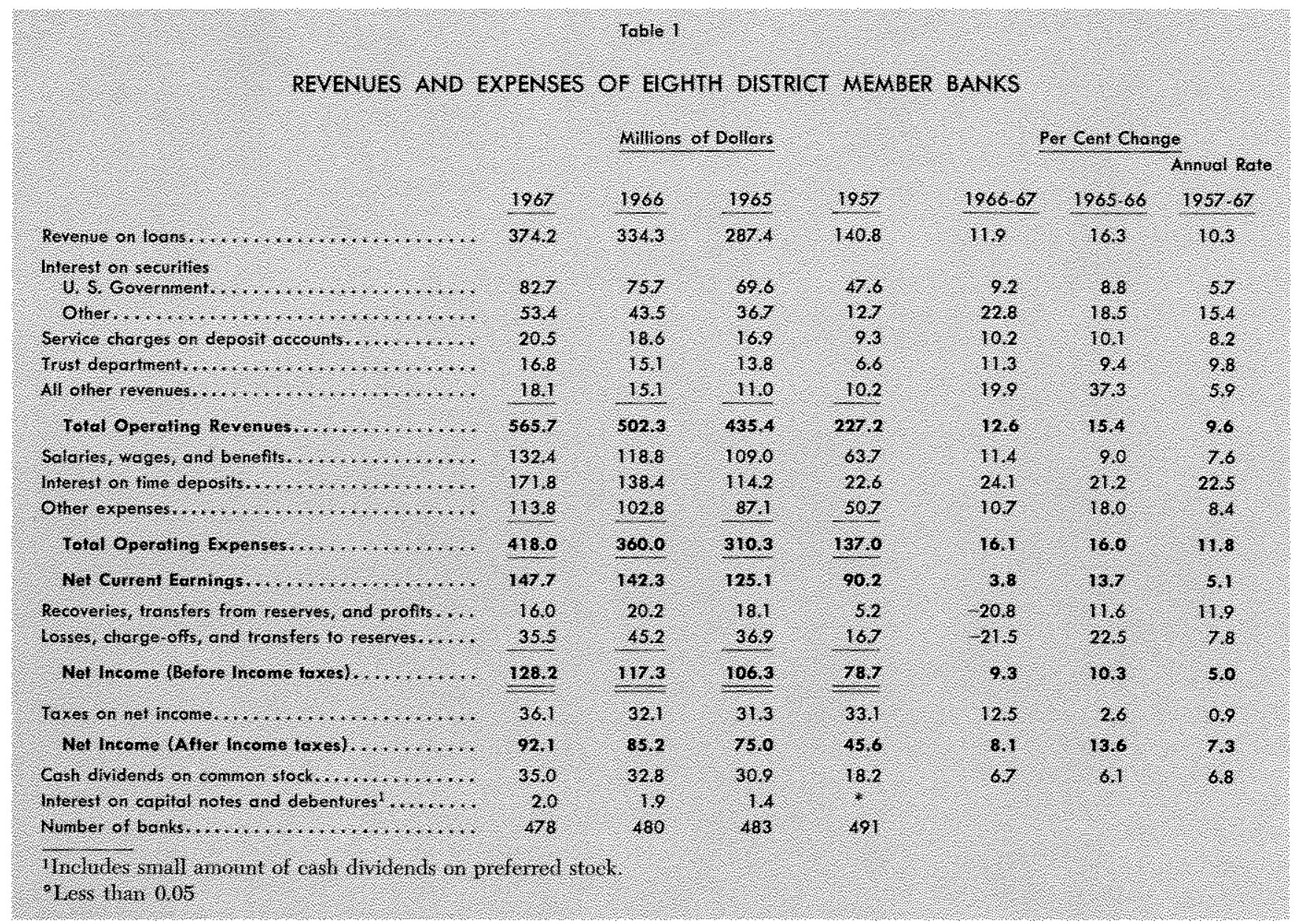

\section{Revemues}

Operating revenues at district member banks totaled $\$ 566$ million in 1967 , an increase of 13 per cent from a year earlier. Major factors influencing this rise were a substantial increase in loans and state and local government securities, along with a slightly higher average rate of return on earning assets.

Although total ievenue increased somewhat more rapidly than loan revenue, the latter accounted for nearly two-thirds of the dollar amount of increase in total revenue from a year earlier. Revenue from securities other than U. S. Government securities (mostly issues of state and local jurisdictions) was the most rapidly rising source of revenue. Income from these sources rose 23 per cent from a year earlier and accounted for almost one-sixth of the gain in total revenue at district member banks. Miscellaneous revenue rose 20 per cent from a year earlier, reflecting the broader range of non-lending services being offered by commercial banks.

Operating revenues at district banks have risen at an average 10 per cent annual rate during the past decade, from $\$ 227$ million in 1957 to $\$ 566$ million in
1967. In addition to an increase in total assets of these banks, the growth in revenue reflects a marked rise in the general level of interest rates, and a shift in the composition of assets, to relatively more of the higher earning types.

Largely as a result of national monetary expansion, total resources of district member banks grew from $\$ 6.6$ billion in 1957 to $\$ 11.9$ billion in 1967 , an average annual increase of 6.1 per cent. Reflecting a slight decline in the proportion of assets in cash balances, earning assets grew somewhat more rapidly, from $\$ 5.0$ billion in 1957 to $\$ 9.4$ billion in 1967 , a 6.4 per cent rate.

In addition to the growth in earning assets, banks have enhanced operating revenues by adjusting the composition of their portfolios to include proportionately more of the higher earning types of assets. Bank holding of U. S. Government securities dropped from 28 per cent of assets in 1957 to 16 per cent in 1967.

These data do not take into account changes in total number of banks, resulting from new member banks, withdrawals from membership, mergers, etc. The effect of such changes in the totals shown would be very minimal. 
Meanwhile, loans rose from 40 per cent to 50 per cent of assets, and "other" securities (mostly tax exempt issues of state and local governments) rose from 8 to 13 per cent.

A major factor tending to increase revenues of banks during the past decade was the upward trend of interest rates. The average return on bank loans increased from 5.3 per cent in 1957 to 6.3 per cent in 1967. Meanwhile, the average return on Government securities rose from 2.6 per cent to 4.5 per cent.

Greater interest and fees charged on bank loans have accounted for a major portion of total bank revenue growth during the past decade. From $\$ 141$ million in 1957, or 62 per cent of the total, revenue from loans rose to $\$ 374$ million in 1967 , or 66 per cent of the total. Returns on loans increased at an average annual rate of 10 per cent during the period.

The most rapidly growing source of revenue over the past decade has been interest on securities other than U. S. Governments. Revenue from these securities rose from $\$ 13$ million in 1957 to $\$ 53$ million in 1967 , an average annual increase of 15 per cent.

Although revenue from U. S. Government securities has continued to rise during the past decade, such revenue has declined as a proportion of total revenue. Interest on Government securities was $\$ 48$ million in 1957,21 per cent of total revenue, while in 1967 such revenue was $\$ 83$ million, 15 per cent of the total. From 1957 to 1967 such revenue rose at an annual rate of 6 per cent.

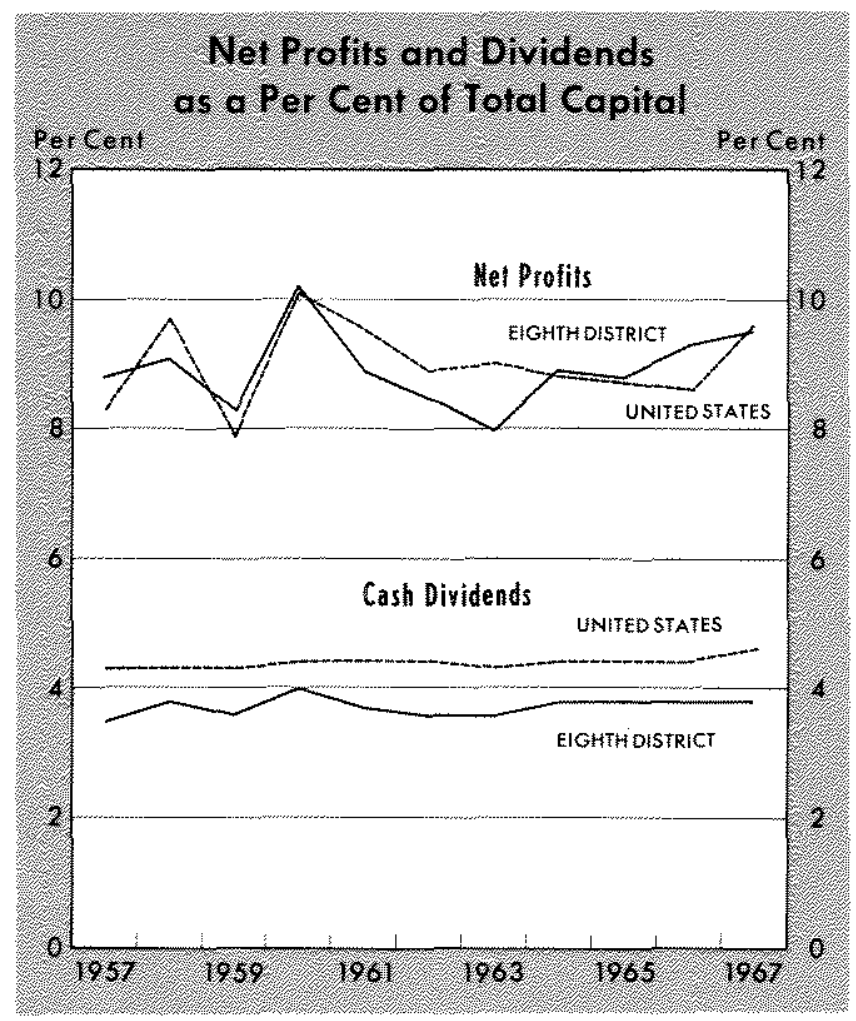

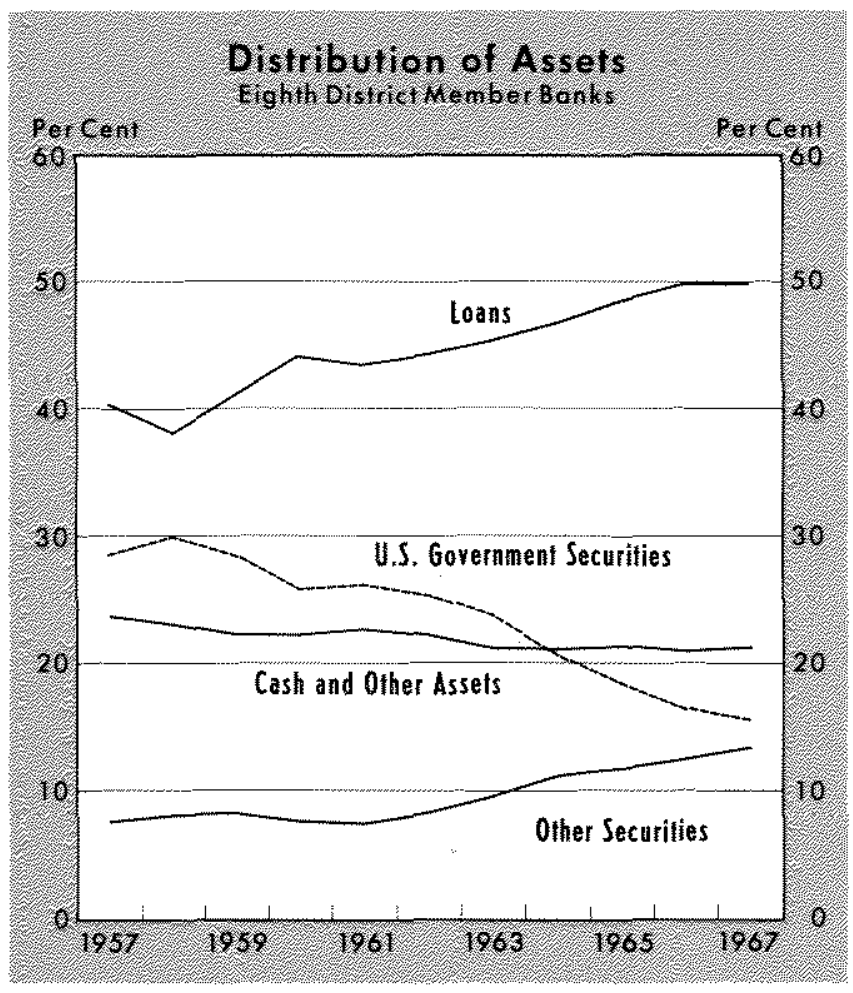

Income from sources other than loans and investments has also grown during the past decade. Service charges on deposit accounts have risen at an average amnual rate of 8 per cent since 1957, and trust department earnings at a 10 per cent rate. Revenue from all other sources showed very little net increase from 1957 through 1965 . In the past two years however, such miscellaneous revenue has expanded rapidly, rising 37 per cent in 1966 and 20 per cent in 1967.

\section{Expones}

Operating expenses at district member banks totaled $\$ 418$ million in 1967 , an increase of 16 per cent from the previous year (Table I). As in most other recent years expenses grew at a more rapid rate, although by a smaller absolute amount, than revenues. Reflecting both the rising interest rates and growth in time and savings deposits, interest paid on time and savings deposits was the most rapidly rising major expense item from 1966 to 1967, increasing 24 per cent. Wages, salaries, and employee benefits rose 11 per cent, as did all other expenses.

Over the past decade operating expenses increased at a high annual rate, but somewhat less than the rise last year. Since 1957 operating expenses of member banks in the district have risen from $\$ 137$ million to $\$ 418$ million, an average annual rate of increase of 12 per cent. A sharply rising volume of time and savings deposits and an upward trend in interest rates paid 


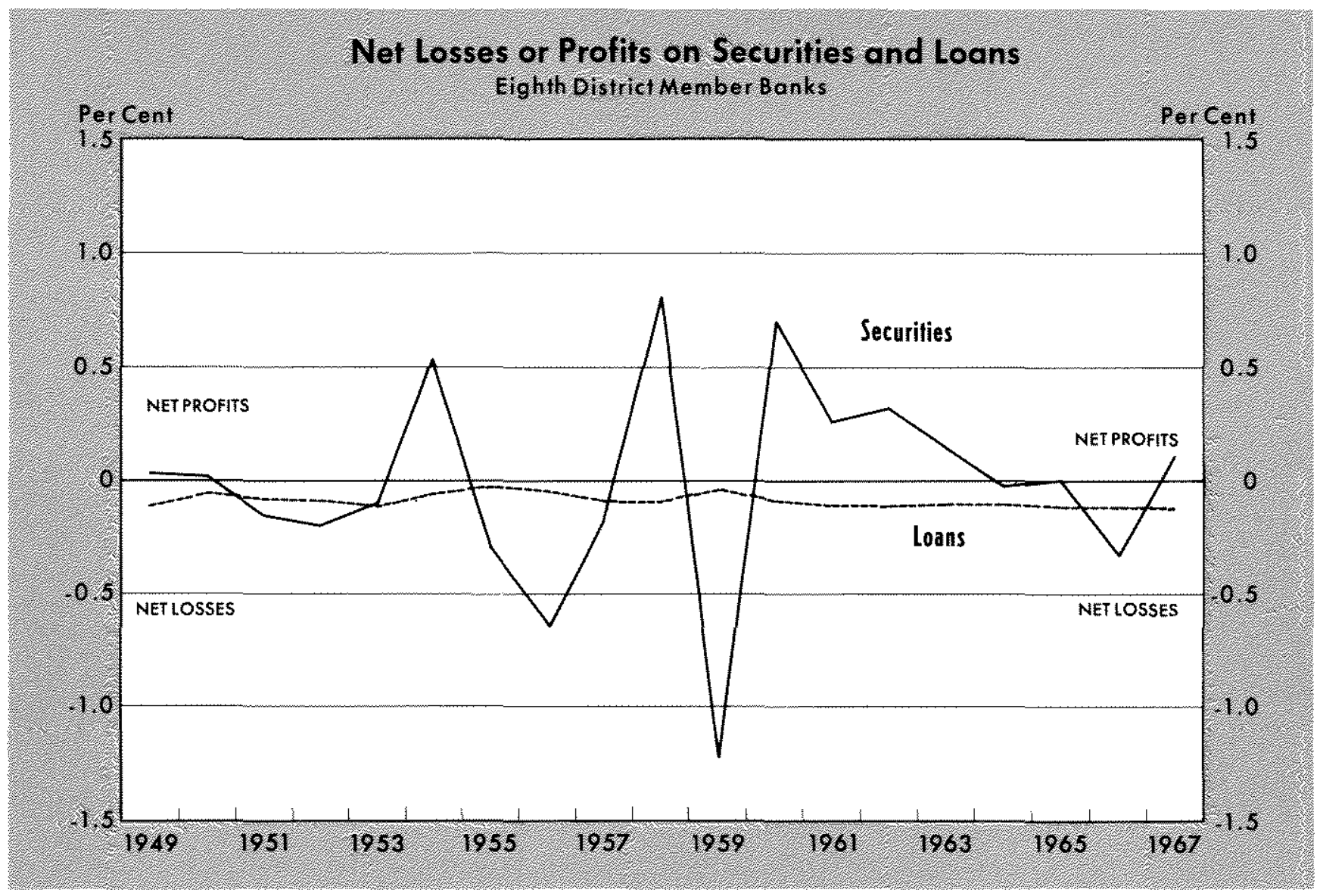

on these accounts have resulted in interest expense accounting for a major portion of the rise in bank operating expenses.

Reflecting the generally rising demand for loanable funds and the competition of financial agencies to obtain such funds, interest paid by banks has increased sharply during the past decade. Interest expense rose from $\$ 23$ million in 1957 to $\$ 172$ million in 1967 , an increase of 23 per cent per year. The volume of time and savings accounts at district banks rose from $\$ 1.3$ billion in 1957 to $\$ 4.2$ billion in 1967 , or 12 per cent per year, while the average rate paid on these accounts rose from 1.68 per cent to 4.07 per cent.

Other major expense items have increased, but less rapidly than interest expense during the past decade. Salaries, wages, and fringe benefits rose at an average annual rate of 7.6 per cent, and all other expenses rose at an 8.4 per cent rate.

District member banks have made sizable gains in the efficient use of labor resources. The number of bank employees in the district has increased less rapidly than either bank assets of loans. Since 1957 the number of employees has dropped from 2.5 per $\$ 1$ million total assets to 1.8 per $\$ 1$ million assets last year. Relative to loans the decline has been even greater. In 1957 member banks in the district employed 6.2 persons per $\$ 1$ million loans outstanding, compared with 3.7 persons in 1967. These trends reflect some gains in economies of scale as banks have grown. Also, there was an increasing efficiency in performing the numerous clerical tasks associated with bank operations, resulting in part from increased adaption of electronic data processing equipment in banking. Reflecting these developments, furniture and equipment expense increased from $\$ 5.8$ million in 1961 (the first year such expense was reported as a separate item) to $\$ 15.3$ million in 1967 , an average annual increase of 17.5 per cent. Of those expense items reported by banks, only interest expense on time and savings deposits rose more rapidly.

\section{Net Losnes on Loms and Secmithes}

Actual losses on loans at district member banks totaled $\$ 7$ million in 1967 , about unchanged from the previous year. The ratio of net losses to total loans was 0.12 per cent, a slight decline from a year earlier.

District member banks experienced net profits on securities of $\$ 3.8$ million in 1967 , compared with net 
losses of $\$ 11$ million in 1966. Several factors contributed to these gains on securities sold. The demand for loans at commercial banks in 1967 was somewhat weaker than in 1966. Consequently, there was less need to sell securities to meet loan demands. In addition, 1966 was a year of depressed securities prices, and banks could take losses which are often favorable on after-tax income. In much of 1967 securities prices were rising, and loss-taking opportunities were not so prevalent.

\section{Net Earnings and Income}

Net current earnings of member banks in the Eighth District totaled $\$ 148$ million in 1967, an increase of 3.8 per cent from a year earlier (Table I). This was somewhat below the average annual increase of 5.1 per cent during the 1957-67 period. The effect of adjustments for net losses, charge-offs, and transfers to valuation reserves, however, was more favorable in 1967 when net current earnings were reduced only $\$ 19.5$ million, compared with a $\$ 25$ million reduction in 1966.

Net income before taxes totaled $\$ 128$ million, an increase of 9 per cent over $\$ 117$ million in 1966. Income taxes rose 13 per cent from the previous year. In addition to the moderate rise in net current earnings, the larger tax payments reflected net profits on security sales, compared with large losses on such sales in 1966.

Net income after taxes at district member banks totaled $\$ 92$ million in 1967 , an increase of 8 per cent and slightly above the trend rate of 7.3 per cent per year during the past decade. In comparison, net income after taxes at all member banks in the nation has risen at an 8.4 per cent rate since 1957 . Net aftertax income relative to capital accounts was 9.5 per cent in 1967, compared with 9.3 per cent a year earlier. During the past decade the ratio of profits to capital at member banks in both the district and the

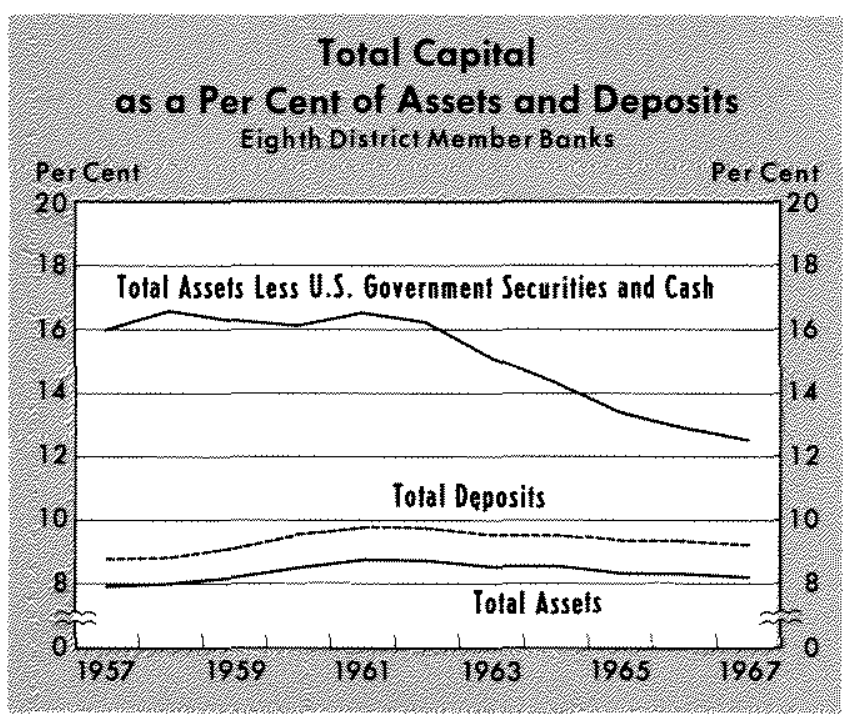

nation has been in the 8 - to - 10 per cent range.

Member banks in the Eighth District distributed dividends on common stock of $\$ 35$ million in 1967, an increase of 6.7 per cent from the previous year. Net retained earnings at these banks totaled $\$ 55$ million. These undivided profits are the primary source of increased capital in banks. In addition, member banks in the district sold $\$ 3.9$ million in capital notes and raised $\$ 3.2$ million of other capital, for a net increase in capital of $\$ 62$ million, 6.7 per cent above yearend 1966.

\section{Conclusions}

The operations of member banks in the district showed somewhat mixed results for the year 1967. Net operating earnings rose somewhat less rapidly than the average rate of gain for the past decade. Although after-tax income of these banks rose 8 per cent, this was considerably less than the 18 per cent gain experienced by all member banks in the nation. Net income relative to capital accounts was 9.5 per cent in 1967, compared with 9.3 per cent in 1966.

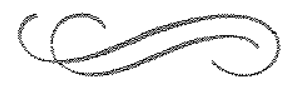

